\title{
Milk production and in sacco disappearance of pasture NDF in grazing Jersey cows receiving a barley based concentrate
}

\author{
M. Lehmann ${ }^{1 \#}$, R. Meeske ${ }^{2}$ and C.W. Cruywagen ${ }^{3}$ \\ ${ }^{1}$ Department of Agricultural Management, Nelson Mandela Metropolitan University: George Campus, \\ Private Bag X 6531, George 6530, South Africa \\ ${ }^{2}$ Department of Agriculture, Western Cape, Outeniqua Experimental Farm, P.O. Box 249, George 6503, South Africa \\ ${ }^{3}$ Department of Animal Sciences, Stellenbosch University, Private Bag X1, Matieland, Stellenbosch 7602, South Africa
}

\begin{abstract}
The aim of the experiment was to determine the effect of feeding low $(2.4 \mathrm{~kg} / \mathrm{d})$, medium $(4.8 \mathrm{~kg} / \mathrm{d})$ and high $(7.2 \mathrm{~kg} / \mathrm{d})$ levels of a barley-based concentrate on milk production and in sacco ruminal disappearance of dry matter (DM) and neutral detergent fibre (NDF) in Jersey cows grazing a Westerwold ryegrass pasture. Sixty Jersey cows in early- to mid lactation were randomly allocated to one of three treatments $(n=20)$. Milk production tended to increase when concentrate level was increased from 2.4 to 4.8 $\mathrm{kg} / \mathrm{day}$. Fat corrected milk yield, milk fat yield and milk fat percentage were not affected by treatment. Protein yield only increased when the concentrate level was increased from 2.4 to $4.8 \mathrm{~kg} / \mathrm{cow}$ per day but there was no further increase when feeding the high level of concentrate. Live weight change and body condition score only increased when the concentrate was fed at $7.2 \mathrm{~kg} / \mathrm{cow}$ per day. An additional 12 Jersey cows, fitted with ruminal cannulae, were randomly allocated to the High and Low concentrate treatments in a two-period crossover design. Rumen liquid samples were collected every four hours for the determination of rumen $\mathrm{pH}$ and volatile fatty acid (VFA) concentrations. Rumen $\mathrm{pH}$ was not affected by treatment while total VFA, acetate and isovalerate concentrations increased when the level of concentrate mixture was increased. Rumen $\mathrm{NH}_{3}-\mathrm{N}$ concentrations were not affected by treatment. The in situ nylon bag technique was used to determine DM and NDF degradation of the pasture. Pasture samples were incubated in the rumen for 0, 4, 8, 12, 20, 30, 48, 72 and 96 hours. Increasing the concentrate mixture did not affect in situ disappearance of pasture DM and NDF, or the rate of degradation. It was concluded that the supplementation of a barley based concentrate to pasture based Jersey cows does not improve animal response when fed at levels higher than $4.8 \mathrm{~kg} / \mathrm{cow}$ per day.
\end{abstract}

Keywords: Milk production, pastures, barley, concentrate feeding, rumen parameters, NDF degradation

${ }^{\#}$ Corresponding author. E-mail: maryna.lehmann@nmmu.ac.za

\section{Introduction}

Supplementing highly digestible pasture with large quantities of rapidly fermentable grains, such as barley, may result in lower milk production, decreased rumen $\mathrm{pH}$, altered rumen volatile fatty acid (VFA) ratios, reduced fibre digestion (Mould \& Ørskov, 1984), milk fat depression (Sutton et al., 1993) and acidosis (Mould et al., 1983). As the level of concentrate feeding increases, the substitution rate increases, and pasture intake decreases (Faverdin et al., 1991). This may result in a deficit of neutral detergent fibre (NDF) in the total diet, less rumination and saliva production, and eventually lower milk production and an altered milk composition (Bargo et al., 2003).

The NRC (2001) recommended that concentrate intake of cows fed total mixed rations should not exceed $25 \mathrm{~g} / \mathrm{kg}$ of live weight, but according to Stockdale et al. (2001) dairy cows grazing on pasture with adequate fibre can ingest much higher quantities of high-energy supplements before milk production and composition or ruminal parameters will be affected. According to a review by Bargo et al. (2003) the results of studies that compared the feeding of different levels of energy sources to cows on pastures are inconsistent due to the influence of numerous factors such as pasture allowance, pasture quality, energy source and substitution rate.

Appropriate strategies for supplementing the diets of grazing dairy cows require an understanding of the interaction of different types of supplements on animal performance, and should be aimed at the provision of nutrients that would complement the nutrients in the pasture. The current study was executed to 
determine the effect of feeding different levels of a barley based concentrate to grazing Jersey cows on milk production and milk composition, as well as on certain rumen parameters and in sacco ruminal disappearance of pasture dry matter (DM) and NDF.

\section{Materials and Methods}

The experiment was conducted from mid-August to end-October 2003 on the Outeniqua Experimental Farm of the Department of Agriculture, Western Cape Province, close to the city of George, situated at $33^{\circ} 58^{\prime} 38^{\prime \prime} \mathrm{S}, 22^{\circ} 25^{\prime} 16$ "E and at an altitude of $210 \mathrm{~m}$. The milk production study consisted of a 21 day adaptation period followed by a 60 day data collection period. Sixty multiparous Jersey cows in early to mid-lactation were blocked and randomly assigned within blocks to one of three treatments. Group averages for days in milk (DIM), lactation number, milk production, live weight (LW) and body condition score (BCS) were similar four weeks prior to the study (Table 1). The treatments consisted of the feeding of a barley-based concentrate at $2.4 \mathrm{~kg}$ (Low), $4.8 \mathrm{~kg}$ (Medium) or $7.2 \mathrm{~kg}$ (High) (“as fed” basis) per cow per day (Table 2). The concentrate mixture was offered in a pelleted form, split into two feedings, at the morning (07:00) and afternoon (16:00) milkings. The composition of the concentrate mixtures is indicated in Table 2.

Table 1 Treatment group means ( \pm s.d.) of days in milk, lactation number, milk production (four weeks prior to study) and live weight $(\mathrm{kg})$ of Jersey cows $(\mathrm{n}=20)$ at the beginning of the study

\begin{tabular}{lrrr}
\hline & \multicolumn{3}{c}{ Treatment $^{1}$ (Feeding levels) } \\
\hline & \multicolumn{1}{c}{ Low } & Medium & High \\
\hline & & & \\
Days in milk & $103 \pm 52.3$ & $98 \pm 50.5$ & $99 \pm 46.9$ \\
Lactation no & $4.1 \pm 2.1$ & $3.5 \pm 1.6$ & $3.9 \pm 1.6$ \\
Milk production (kg) & $13.2 \pm 3.2$ & $13.5 \pm 3.2$ & $13.3 \pm 2.9$ \\
Live weight (kg) & $357 \pm 7.4$ & $359 \pm 31.1$ & $353 \pm 27.1$ \\
Body condition score (BCS: 1-5) & $2.17 \pm 0.28$ & $2.12 \pm 0.31$ & $2.13 \pm 0.22$
\end{tabular}

${ }^{1}$ Treatment: Barley-based concentrate offered in equal amounts at 07:00 and 16:00

Low $=2.4 \mathrm{~kg} / \mathrm{cow}$ per day; Medium $=4.8 \mathrm{~kg} / \mathrm{cow}$ per day; High $=7.2 \mathrm{~kg} / \mathrm{cow}$ per day

The LW and BCS of each cow were determined at the beginning and end of the experimental period. To calculate the mean weights cows were weighed on a Tru-test Ezi weigh version 1.0 scale $(0.5 \mathrm{~kg}$ accuracy) after the morning milking on two consecutive days. Body condition score was determined according to a five-point scale (Mulvany, 1977). To ensure consistency, the same person determined BCS at the beginning and end of the experiment.

The cows grazed a kikuyu pasture that had been over-sown during March (autumn) with ryegrass (Lolium multiflorum - cv Energa) at $20 \mathrm{~kg}$ seed/ha. The pasture consisted predominantly of ryegrass since kikuyu is dormant during August and September in the Southern Cape (Botha, 2003). Pasture was offered at ca. $12 \mathrm{~kg} \mathrm{DM} / \mathrm{cow}$ per day to ensure that pasture intake was not limiting. Fertilizer was applied at $56 \mathrm{~kg} \mathrm{~N}$ in the form of limestone ammonium nitrate (LAN) after each paddock has been grazed down.

Pasture samples were collected for chemical analyses by cutting three areas of $0.1 \mathrm{~m}^{2}$ at a height of $3 \mathrm{~cm}$ on Mondays, Wednesdays and Fridays. The samples required for the determination of in sacco NDF and DM disappearance were cut simultaneously at a height of $3 \mathrm{~cm}$. All the samples were weighed on a Sartorius BP8100 ( $\mathrm{d}=0.1 \mathrm{~g})$ balance and dried at $60^{\circ} \mathrm{C}$ for 72 hours in a Labcon Economy force-draft oven to determine DM content. Pooled samples for each seven days of the experimental period were then milled through a $2 \mathrm{~mm}$ screen with a Retsch GmbH5657 Type SMI 31405 laboratory mill. The samples for the chemical analysis were stored at $-20^{\circ} \mathrm{C}$ while the those for the in sacco NDF and DM disappearance study were stored in airtight plastic containers.

Grab samples of the concentrate mixtures were also collected on Mondays, Wednesdays and Fridays, pooled for each seven days of the experimental period, weighed, dried for DM determination, milled and stored in a similar way as the pasture samples. 
During the data collection period milk production was recorded at each milking, and milk samples were collected once a week during the afternoon and morning milkings. These samples were preserved with sodium dichromate, stored in containers and sent to the laboratory immediately after the morning milking for analyses of milk fat and protein content. Milk yields were converted to a $4 \%$ fat corrected milk $[\mathrm{FCM}=(0.4 \times \mathrm{kg}$ milk $)+(15 \mathrm{x}$ kg butterfat $)]$ basis.

Pasture and concentrate samples of the feed offered were analyzed for DM, organic matter (OM), calcium, phosphorus and crude protein ( $\mathrm{N} \times$ 6.25), according to procedures of the AOAC (1995). Neutral detergent fibre was determined by heating a $0.5 \mathrm{~g}$ sample to boiling point in $100 \mathrm{~mL}$ of neutral detergent plus $50 \mu \mathrm{L}$ of heat stable amylase (Dietary fiber kit; Sigma catalogue Number 3306) added before heating. Sodium sulphate was not added; the sample was boiled for one hour and filtered (Van Soest et al., 1991). Acid detergent fibre was determined according to the method of Goering \& Van Soest (1970). The in vitro organic matter digestibility (IVOMD) was determined according to the Tilley \& Terry (1963) method. The metabolisable energy (ME) content was calculated according to ARC (1984) as:

$\mathrm{ME}(\mathrm{MJ} / \mathrm{kg} \mathrm{DM})=18.4 \times \mathrm{IVOMD} \times 0.81$.

An analysis of variance was performed on all variables using the GLM procedure of SAS (1996). Milk production four weeks prior to the experiment was used as a covariate. Adjusted means (means adjusted for effects in the model) were calculated for the production study data using the LSMeans option of the GLM Procedure of SAS. P-values for all pair-wise differences (Tukey multiple comparison test) of the LSMeans were produced to compare treatment means.

Table 2 Physical and chemical composition of the barley-based concentrate used to supplement the diet of pasture based Jersey cows

\begin{tabular}{|c|c|}
\hline Item & Amount \\
\hline \multicolumn{2}{|c|}{ Physical composition (g /kg, air dry) } \\
\hline Barley & 868 \\
\hline Cotton seed oil cake & 90 \\
\hline Urea & 0 \\
\hline Bran & 5.0 \\
\hline DiCaP & 13 \\
\hline Feed lime & 12 \\
\hline Salt & 5 \\
\hline $\mathrm{MgO}$ & 5 \\
\hline Premix ${ }^{1}$ & 2 \\
\hline \multicolumn{2}{|c|}{ Chemical composition (g/kg dry matter) } \\
\hline Dry matter & 962 \\
\hline Ash & 77 \\
\hline Nitrogen & 19.5 \\
\hline Crude protein & 122 \\
\hline IVOMD & 836 \\
\hline $\mathrm{ME}(\mathrm{MJ} / \mathrm{kg})$ & 12.4 \\
\hline Neutral detergent fibre & 271 \\
\hline Calcium & 10 \\
\hline Phosphorus & 9 \\
\hline
\end{tabular}

${ }^{1}$ Each 2 kg premix contained: 10000000 IU vitamin A; 1000000 IU vitamin $\mathrm{D}_{3} ; 20000$ IU vitamin E; 193 g Mn; 262 g Zn; 100 g Fe; 45 g Cu; 4 g I; 0.5 g Se; 4.32 g Co

IVOMD - in vitro organic matter digestibility

$\mathrm{ME}$ - metabolisable energy (ME) (calculated)

Twelve additional lactating Jersey cows, fitted with ruminal cannulae $(100 \mathrm{~mm}$, internal diameter; Bar Diamond Inc., P.O. Box 60, Parma, ID, USA), were randomly allocated to the Low and High concentrate treatments and received either 2.4 or $7.2 \mathrm{~kg}$ of concentrate per cow/d in a two-period cross-over design (A 
14-day adaptation period, followed by a 7-day measurement period). The cannulated cows grazed with the 60 cows in the milk production study. Six rumen liquor samples were collected at 4-hour intervals (06:00, 10:00, 14:00, 18:00, 22:00 and 02:00) during a 24-hour cycle. The procedure was repeated once.

After taking a sample of rumen liquid, $\mathrm{pH}$ was measured immediately with a portable $\mathrm{pH}$ meter. The fluid was filtered through a double layer of cheesecloth to remove large particles and was sealed in an airtight container. Two separate $9 \mathrm{~mL}$ rumen liquid samples were preserved by adding either $1 \mathrm{~mL}$ of a $10 \%$ (v/v) $\mathrm{NaOH}$ (for VFA analysis) or $1 \mathrm{~mL}$ of a $50 \%(\mathrm{v} / \mathrm{v}) \mathrm{H}_{2} \mathrm{SO}_{4}$ solution (for rumen- $\mathrm{NH}_{3}$ analysis). Samples were stored at $-20^{\circ} \mathrm{C}$ until analyzed. Both VFA and $\mathrm{NH}_{3}$ analyses were according to AOAC (1995) procedures.

The nylon bag technique was used to estimate in sacco NDF and DM degradability values of pasture samples (Huntington \& Givens, 1995). Dried pasture samples of approximately $8 \mathrm{~g}$ herbage were accurately weighed out into nylon bags (100 x 200 mm, mean pore size 50 ( \pm 15$) \mu \mathrm{m}$; Bar Diamond Inc.). Bags were sealed with a plastic tie and placed into nylon stocking carrier bags for incubation, according to the method described by Cruywagen (2006, Personal communication. Dept. Anim. Sci., Stellenbosch University, Private Bag X1, Matieland, Stellenbosch 7602, South Africa). Bags were inserted into the rumen simultaneously and incubated for $0,4,8,12,20,30,48,72$ and 96 hours. Time 0 entailed of the soaking and hand washing of bags in cold water for 10 minutes. Following ruminal incubation, all bags were washed in a similar way. Excess fluid was carefully squeezed from the bags and the bags were oven-dried at $60{ }^{\circ} \mathrm{C}$ for 72 hours. Residues were analyzed for DM and NDF content.

The DM and NDF disappearance values were determined and expressed as a proportion of DM and NDF incubated, respectively. Data were fitted to the following exponential model (Ørskov \& Mc Donald, 1979):

$\mathrm{P}=\mathrm{a}+\mathrm{b}\left(1-\exp ^{-\mathrm{ct}}\right)$

where: $\mathrm{P}=\mathrm{DM}$ or NDF disappearance at incubation time $\mathrm{t}$;

$\mathrm{a}=$ disappearance at time 0 , representing the soluble and completely degradable fraction;

$\mathrm{b}=$ slowly degradable fraction or the difference between the intercept (a) and asymptote;

$\mathrm{c}=$ rate $(/ \mathrm{h})$ at which $\mathrm{b}$ is degraded.

The maximum extent of degradation (total potentially degradable fraction) would be indicated by $\mathrm{a}+\mathrm{b}$.

Analysis of variance was performed on the derived non-linear parameters ( $a, b$ and c) using the GLM procedure of SAS (1996). Differences between means were determined by the least significant difference (LSD) range test method. Significance was declared at $\mathrm{P}<0.05$.

\section{Results and Discussion}

On a DM basis, the ryegrass pasture contained 129 g ash/kg; 40 g N/kg; 251 g CP/kg; 11.3 MJ ME/kg; $5 \mathrm{~g} \mathrm{Ca} / \mathrm{kg} ; 5 \mathrm{~g} \mathrm{P} / \mathrm{kg} \mathrm{P}$; $444 \mathrm{~g} \mathrm{NDF} / \mathrm{kg}$ and had an IVOMD of 75.6\%. The milk production, milk composition, live weight change (LWC) and BCS results are presented in Table 3. Rumen volatile fatty acid and rumen $\mathrm{NH}_{3}-\mathrm{N}$ results are presented in Table 4, rumen pH results in Table 5 and in sacco trial results in Table 6.

The results in Table 3 indicate that the milk production tended to increase $(\mathrm{P}<0.10)$ when the concentrate level was increased from 2.4 to $4.8 \mathrm{~kg} / \mathrm{cow}$ per day. Although an analysis of co-variance with initial milk yield as the covariate was applied, an increase in concentrate feeding did not result in an increase in FCM, milk fat yield or milk fat percentage. Furthermore, an increased concentrate level was not associated with milk fat depression, suggesting that the pasture NDF (440 g/kg) was sufficient to meet the fibre requirements for maintenance of milk fat production. Mould et al. (1983) reported similar results.

Milk protein percentage increased when the concentrate level was increased from 4.8 to $7.2 \mathrm{~kg} / \mathrm{cow}$ per day. Several authors, cited by Bargo et al. (2003), also reported an increase in milk protein percentage with increasing levels of supplementation. Milk protein yield increased when concentrate feeding was increased to $4.8 \mathrm{~kg} / \mathrm{cow}$ per day but there was no further response when the level was increased to 7.2 $\mathrm{kg} / \mathrm{cow}$ per day. 
Table 3 Milk production, milk composition, live weight change (LWC), and body condition score (BCS) values obtained from Jersey cows on ryegrass pasture, fed low, medium, or high levels of a barley-based concentrate

\begin{tabular}{|c|c|c|c|c|c|c|c|}
\hline \multirow{2}{*}{ Parameters } & \multicolumn{3}{|c|}{ Treatment ${ }^{1}$} & \multicolumn{4}{|c|}{ Significance of differences between treatments } \\
\hline & Low & Medium & High & LSD & L vs. M & L vs. H & M vs. H \\
\hline Milk, (kg/day) & 17.3 & 19.1 & 18.1 & 1.98 & $*$ & NS & NS \\
\hline FCM, (kg/day) & 18.4 & 20.0 & 19.1 & 2.10 & NS & NS & NS \\
\hline Milk fat (\%) & 4.42 & 4.35 & 4.37 & 0.30 & NS & NS & NS \\
\hline Milk fat yield (kg) & 0.76 & 0.82 & 0.79 & 0.09 & NS & NS & NS \\
\hline Protein (\%) & 3.39 & 3.43 & 3.51 & 0.11 & NS & $* *$ & $*$ \\
\hline Protein yield (kg) & 0.59 & 0.65 & 0.63 & 0.07 & $* *$ & NS & NS \\
\hline LWC (kg) & 17.9 & 19.1 & 29.0 & 8.58 & NS & $* *$ & $* *$ \\
\hline BCS change (scale 1-5) & 0.35 & 0.55 & 0.70 & 0.33 & NS & $* *$ & NS \\
\hline
\end{tabular}

${ }^{1}$ Treatment: Barley-based concentrate offered in equal amounts at 07:00 and 16:00

Low $=2.4 \mathrm{~kg} /$ cow per day; Medium $=4.8 \mathrm{~kg} / \mathrm{cow}$ per day; High $=7.2 \mathrm{~kg} / \mathrm{cow}$ per day

$\mathrm{FCM}=4 \%$ fat corrected milk $(0.4 \mathrm{x} \mathrm{kg}$ milk $)+(15 \mathrm{x} \mathrm{kg}$ butterfat $)$

$\mathrm{BCS}=$ body condition score measured at a scale of $1-5 ; 1=$ extremely thin, $5=$ obese

LSD $=$ Least significant difference at $\mathrm{P}=0.05$

$* \mathrm{P}<0.10 ; * * \mathrm{P}<0.05$ and NS $=$ not significant

Table 4 Mean total volatile fatty acid (VFA) concentrations, molar VFA proportions and rumen ammonia-N concentrations in rumen liquid obtained at 4-hourly intervals over a 24-hour cycle from Jersey cows $(\mathrm{n}=12)$ grazing Westerwold-ryegrass pasture and receiving a low or high level of a barley-based concentrate

\begin{tabular}{|c|c|c|c|c|}
\hline \multirow{2}{*}{ Parameters } & \multicolumn{2}{|c|}{ Treatment $^{1}$} & \multirow[b]{2}{*}{ LSD } & \multirow[b]{2}{*}{ P-value } \\
\hline & Low & High & & \\
\hline Total VFA (mM/L) & $118.1^{\mathrm{a}}$ & $139.4^{\mathrm{b}}$ & 15.88 & 0.015 \\
\hline Acetate (mM/L) & $83.9^{\mathrm{a}}$ & $101.9^{\mathrm{b}}$ & 13.33 & 0.014 \\
\hline Propionate (mM/L) & $18.7^{\mathrm{a}}$ & $20.3^{\mathrm{a}}$ & 5.42 & 0.465 \\
\hline Acetate:Proprionate Ratio & $12.0^{\mathrm{a}}$ & $9.3^{\mathrm{a}}$ & 3.23 & 0.597 \\
\hline n-Butyrate (mM/L) & $14.5^{\mathrm{a}}$ & $15.7^{\mathrm{a}}$ & 3.60 & 0.631 \\
\hline n-Valerate (mM/L) & $0.29^{\mathrm{a}}$ & $0.47^{\mathrm{a}}$ & 0.31 & 0.231 \\
\hline Isobutyrate (mM/L) & $0.74^{\mathrm{a}}$ & $0.70^{\mathrm{a}}$ & 0.21 & 0.783 \\
\hline Isovalerate (mM/L) & $0.009^{\mathrm{a}}$ & $0.248^{b}$ & 0.13 & 0.003 \\
\hline $\mathrm{NH}_{3}-\mathrm{N}(\mathrm{mg} / \mathrm{dL})$ & $11.9^{\mathrm{a}}$ & $10.0^{\mathrm{a}}$ & 1.71 & 0.124 \\
\hline
\end{tabular}

${ }^{1}$ Treatment: Barley-based concentrate offered in equal amounts at 07:00 and 16:00

Low $=2.4 \mathrm{~kg} /$ cow per day; Medium $=4.8 \mathrm{~kg} / \mathrm{cow}$ per day; High $=7.2 \mathrm{~kg} / \mathrm{cow}$ per day

LSD $=$ Least significant difference at $\mathrm{P}=0.05$

${ }^{\mathrm{a}, \mathrm{b}}$ Means within a row with different superscripts differed $(\mathrm{P}<0.05)$ 
Table 5 Rumen $\mathrm{pH}$ values obtained at 4-hourly intervals over a 24-hour cycle from Jersey cows $(\mathrm{n}=12)$ grazing Westerwold-ryegrass pasture and receiving low or high levels of a barley-based concentrate

\begin{tabular}{ccccc}
\hline & \multicolumn{2}{c}{ Treatment $^{1}$} & & \\
\hline Time & Low & High & LSD & P-value \\
\hline $06: 00$ & $6.3^{\mathrm{a}}$ & $6.4^{\mathrm{a}}$ & 0.341 & 0.809 \\
$10: 00$ & $6.5^{\mathrm{a}}$ & $6.2^{\mathrm{b}}$ & 0.147 & 0.001 \\
$14: 00$ & $6.2^{\mathrm{a}}$ & $6.3^{\mathrm{a}}$ & 0.125 & 0.209 \\
$18: 00$ & $5.9^{\mathrm{a}}$ & $5.8^{\mathrm{a}}$ & 0.234 & 0.491 \\
$22: 00$ & $5.8^{\mathrm{a}}$ & $5.9^{\mathrm{a}}$ & 0.214 & 0.286 \\
$02: 00$ & $6.3^{\mathrm{a}}$ & $6.4^{\mathrm{b}}$ & 0.155 & 0.050 \\
Average pH & $6.2^{\mathrm{a}}$ & $6.2^{\mathrm{a}}$ & 0.120 & 0.907 \\
\hline
\end{tabular}

${ }^{1}$ Treatment: Barley-based concentrate offered in equal amounts at 07:00 and 16:00

Low $=2.4 \mathrm{~kg} / \mathrm{cow}$ per day; Medium $=4.8 \mathrm{~kg} / \mathrm{cow}$ per day; High $=7.2 \mathrm{~kg} / \mathrm{cow}$ per day

LSD $=$ Least significant difference at $\mathrm{P}=0.05$

${ }^{\mathrm{ab}}$ Means within a row with different superscripts differed $(\mathrm{P}<0.05)$

Table 6 In sacco ruminal dry matter (DM)- and neutral detergent fibre (NDF) degradability values of Westerwold-ryegrass pasture grazed by Jersey cows $(n=12)$ receiving low or high levels of a barley-based concentrate

\begin{tabular}{|c|c|c|c|c|}
\hline \multirow{2}{*}{ Parameters } & \multicolumn{2}{|c|}{ Treatment $^{1}$} & \multirow[b]{2}{*}{ LSD } & \multirow[b]{2}{*}{ P-value } \\
\hline & Low & High & & \\
\hline \multicolumn{5}{|l|}{ DM degradability $^{2}$} \\
\hline a & $41.7^{\mathrm{a}}$ & $43.1^{\mathrm{a}}$ & 1.90 & 0.128 \\
\hline b & $52.9^{\mathrm{a}}$ & $51.4^{\mathrm{a}}$ & 2.99 & 0.262 \\
\hline $\mathrm{c}$ & $0.05^{\mathrm{a}}$ & $0.05^{\mathrm{a}}$ & 0.01 & 0.363 \\
\hline $\mathrm{PD}(\mathrm{a}+\mathrm{b})$ & $94.7^{\mathrm{a}}$ & $94.5^{\mathrm{a}}$ & 3.97 & 0.919 \\
\hline \multicolumn{5}{|l|}{ NDF degradability ${ }^{2}$} \\
\hline a & $15.2^{\mathrm{a}}$ & $17.2^{\mathrm{a}}$ & 2.60 & 0.119 \\
\hline $\mathrm{b}$ & $77.0^{\mathrm{a}}$ & $77.3^{\mathrm{a}}$ & 4.68 & 0.894 \\
\hline c & $0.05^{\mathrm{a}}$ & $0.04^{\mathrm{a}}$ & 0.01 & 0.207 \\
\hline $\mathrm{PD}(\mathrm{a}+\mathrm{b})$ & $92.2^{\mathrm{a}}$ & $94.4^{\mathrm{a}}$ & 6.46 & 0.451 \\
\hline \multicolumn{5}{|c|}{${ }^{1}$ Treatment: Barley-based concentrate offered in equal amounts at 07:00 and 16:00 } \\
\hline \multirow{3}{*}{\multicolumn{5}{|c|}{$\begin{array}{l}\text { Low }=2.4 \mathrm{~kg} / \mathrm{cow} \text { per day; Medium }=4.8 \mathrm{~kg} / \mathrm{cow} \text { per day; High }=7.2 \mathrm{~kg} / \mathrm{cow} \text { per day } \\
{ }^{2} \text { Non-linear parameters a }=\text { soluble fraction, } \mathrm{b}=\text { Potentially degradable fraction, } \\
\mathrm{c}=\text { rate at which } \mathrm{b} \text { is degraded in the rumen }\end{array}$}} \\
\hline & & & & \\
\hline & & & & \\
\hline \multicolumn{5}{|c|}{ LSD = Least significant difference at $\mathrm{P}=0.05$} \\
\hline
\end{tabular}

Live weight changes (LWC) and BCS changes were significantly higher for the treatment group that received $7.2 \mathrm{~kg} / \mathrm{cow}$ per day than for the other groups. This was possibly due to higher energy intake and more nutrients being partitioned to live weight gain rather than to milk production (Bargo et al., 2003). Numerous factors, such as milk production, body condition score, age, parity, diet and hormones may influence LWC, but their measurements are often not reliable over a short period of time. Performance of this experiment was measured over 74 days and should be interpreted with caution (Komaragiri \& Erdman, 1996). 
At 10:00 rumen $\mathrm{pH}$ was lower in cows receiving the high concentrate treatment compared to those on the low concentrate treatment. This was probably due to the more extensive and faster fermentation of the higher amount of starch ingested by the High than the Low group. However, at 02:00 the rumen $\mathrm{pH}$ was higher in the cows on the high concentrate level compared to those on the low concentrate treatment, indicating that the $\mathrm{pH}$ in those cows was restored. At all other times level of concentrate did not affect rumen $\mathrm{pH}$. From 02:00 to 14:00 the rumen $\mathrm{pH}$ was still well within the range of 6.0 to 6.9 that promotes optimal fibre digestion (Pitt et al., 1996; Kolver et al., 1998). The range of ruminal $\mathrm{pH}$ is not the only factor that needs consideration, but the extent of $\mathrm{pH}$ depression and the duration thereof below 6.0 could also affect fibre digestion (Ørskov \& Istasse, 1983). The $\mathrm{pH}$ was higher just prior to feeding and seemed to reach a minimum between 18:00 and 22:00. The extent of $\mathrm{pH}$ depression was similar for both treatment groups and never declined below 5.6 where fibre digestion is impaired. According to Beauchemin (1999) a continuous low $\mathrm{pH}$ is required to decrease ruminal digestion. In the current trial the $\mathrm{pH}$ was below 6 at 18:00 and 22:00. Since $\mathrm{pH}$ was only measured every four hours, the actual duration of $\mathrm{pH}$ values below 6 is unknown. Results of studies on the effect of the amount of concentrate supplementation on ruminal $\mathrm{pH}$ of dairy cows on pasture are inconsistent and suggest that there is no simple relationship between the amount of concentrate supplemented and the ruminal $\mathrm{pH}$ response (Bargo et al., 2003). The interaction between the amount and type of concentrate supplemented, pasture dry mater intake and pasture quality may all play a role (Bargo et al., 2003).

Although rumen $\mathrm{pH}$ was not affected by treatment in this study, total VFA concentrations increased when concentrate level was increased to $7.2 \mathrm{~kg} / \mathrm{cow}$ per day. This was due to an increase in acetate and iso-valerate concentrations. Some of the publications reviewed by Bargo et al. (2002) supported the fact that supplementation is associated with an increase in total VFA concentrations, yet the majority (Van Vuuren et al., 1986; Sayers, 1999; Reis \& Combs, 2000) reported no effect of supplementation on total VFA concentrations even with reductions in $\mathrm{pH}$ (Carruthers \& Neil, 1997).

Carruthers et al. (1997) and Casper et al. (1999) reported that supplementation consistently reduced ruminal $\mathrm{NH}_{3}-\mathrm{N}$ concentrations and that this could be associated with a higher capture of $\mathrm{NH}_{3}$ from the highly degradable pasture CP. In the current study, however, an increase in concentrate intake (from 2.4 to 7.2 $\mathrm{kg}$ /day) had no effect on rumen $\mathrm{NH}_{3}-\mathrm{N}$ concentrations. Khorasani et al. (1994) and Satter \& Slyter (1974) reported similar results. It can be postulated that $2.4 \mathrm{~kg}$ concentrate/cow per day provided sufficient energy for $\mathrm{NH}_{3}-\mathrm{N}$ capturing and that additional supplementation had no further effect. Because there was no treatment without any concentrate supplementation, this hypothesis could not be tested. No other rumen parameters were affected with an increase in the level of concentrates fed.

Results presented in Table 6 show that an increase in concentrate supplementation to $7.2 \mathrm{~kg} / \mathrm{cow}$ per day did not affect the rate or potential degradability of DM or NDF of the ryegrass pasture.

Rumen liquid $\mathrm{pH}, \mathrm{NH}_{3}-\mathrm{N}$ and total VFA concentrations, and the potential degradability (PD) of the pasture were within the ranges reported by Bargo et al. (2003), viz. $\mathrm{pH}$ of $5.8-6.3, \mathrm{NH}_{3}-\mathrm{N}$ of concentrations 8.7 - $32.2 \mathrm{mg} / \mathrm{dL}$, total VFA concentrations of 90.3 - $151.4 \mathrm{mMol} / \mathrm{L}$ and $\mathrm{PD}$ values of 89.5 - 93.5\%. Increasing the amount of concentrate mixture did not affect in situ pasture digestion or the rate of degradation and confirms that concentrate supplementation only affects in situ ruminal digestion of pasture when fed at quantities higher than $8 \mathrm{~kg} \mathrm{DM} /$ cow per day (Bargo et al., 2003).

\section{Conclusion}

Daily milk production and protein yield tended to increase when the level of concentrate supplementation increased from 2.4 to $4.8 \mathrm{~kg} / \mathrm{cow}$ per day. Although there was no further increase in milk production when $7.2 \mathrm{~kg} / \mathrm{cow}$ per day was fed, BCS increased and it is postulated that additional nutrients were partitioned to weight gain rather than to milk production. Milk protein percentage increased when concentrate levels were increased from 4.8 to $7.2 \mathrm{~kg} / \mathrm{cow}$ per day, possibly due to an increased energy intake.

The absence of a depression in milk fat yield and concentration with an increase in concentrate level was reflected in a similar rumen $\mathrm{pH}$ profile in cows receiving the low and high levels of concentrate. This agrees with the findings of Stockdale et al. (2001), namely that dairy cows grazing good quality pasture can ingest relatively large quantities of high-energy supplements before milk fat depression occurs. Concentrate feeding did not have an effect on ruminal in situ DM or NDF digestion in Jersey cows fed up to $7.2 \mathrm{~kg}$ barley-based concentrate per day. Finally, it is concluded that the feeding of more than $4.8 \mathrm{~kg}$ of a pelleted barley based concentrate to Jersey cows grazing high quality annual ryegrass is not recommended. 


\section{Acknowledgement}

The National Research Foundation (NRF): GUN No 2045676, the Nelson Mandela Metropolitan University, Department of Animal Sciences, Stellenbosch University, Department of Agriculture, Western Cape and the personnel of Outeniqua Experimental Farm at George are gratefully acknowledged for their contributions to the investigation.

\section{References}

AOAC, 1995. Association of Official Analytical Chemists International. Official Methods of Analysis of AOAC International, 16th Ed., Methods 4.2.02 (954.01), AOAC International, Maryland, USA.

ARC, 1984. The Nutrient Requirements of Ruminant Livestock. Agriculture Research Council. The Lavenham Press, LTD., Lavenham, Suffolk, UK. pp. 59-60.

Bargo, F., Muller, L.D., Delahoy, J.E. \& Cassidy, T.W., 2002. Milk response to concentrate supplementation of high producing dairy cows grazing on two pasture allowances. J. Dairy Sci. 85, 1777-1792.

Bargo, F., Muller, L.D., Kolver, E.S. \& Delahoy, J.E., 2003. Invited review: Production and digestion of supplemented dairy cows on pasture. J. Dairy Sci. 86, 1-42.

Beauchemin, K.A. \& Rode, L.M., 1999. Effects of grain source and enzyme additive on site and extent of nutrient digestion in dairy cows. J. Dairy Sci. 82, 378-390.

Botha, P., 2003. Die produksiepotensiaal van oorgesaaide kikuyu weiding in die gematigde kusgebied aan die Suid-Kaap. Ph.D tesis, UOVS. pp. 117-118.

Carruthers, V.R. \& Neil, P.G., 1997. Milk production and ruminal metabolites from cows offered two pasture diets supplemented with non-structural carbohydrate. N. Z. J. Agric. Res. 40, 513-521.

Carruthers, V.R., Neil, P.G. \& Dalley, D.E., 1997. Effect of altering the non-structural: structural carbohydrate ratio in a pasture diet on milk production and ruminal metabolites in cows in early and late lactation. Anim. Sci. 64, 393-402.

Casper, D.P., Maiga, H.A., Brouk, M.J. \& Schingoethe, D.J., 1999. Synchronization of carbohydrate and protein sources on fermentation and passage rate in dairy cows. J. Dairy Sci. 82, 1779-1790.

Faverdin, P., Dulphy, J.P., Coulon, J.B., Vérité, R., Garel, J.P., Rouel, J. \& Marquis, B., 1991. Substitution of roughage by concentrates for dairy cows. Livest. Prod. Sci. 27, 137-156.

Friggens, N., Emmans, G.C., Robertson, S., Chamberlain, D.G., Whittemore, C.T. \& Oldham, J.D., 1995. The lactation responses of dairy cows to amount of feed and to the source of carbohydrate energy. J. Dairy Sci. 78, 1734-1743.

Goering, H.K. \& Van Soest, P.J., 1970. Forage Fiber Analysis (apparatus, reagents, procedures and some applications). U.S.D.A.-A.R.S. Agriculture Handbook no. 379, Government Printing Office, Washington, D.C., USA.

Huntington, J.A. \& Givens, D.I., 1995. The in situ technique for studying the rumen degradation of feeds: A review: Proc. Nutr. Abs. Rev. (Series B). 65, No. 2. pp. 63-78.

IDF, 1996. International Dairy Federation, International IDF Standard 141B . General Secretariat, May 1996.

Khorasani, G.R., de Boer, G., Robinson, B. \& Kennely, J.J., 1994. Influence of dietary protein and starch on production and metabolic responses of dairy cows. J. Dairy Sci. 77, 813-824.

Kolver, E.S., Muller, L.D., Barry, M.C. \& Penno, J.W., 1998. Evaluation and application of the Cornell Net Carbohydrate and Protein System for dairy cows fed diets based on pasture. J. Dairy Sci. 81, 2029-2039.

Komaragiri, M.V.S. \& Erdman, R.A., 1996. Factors affecting body tissue mobilization in early lactation dairy cows. J. Dairy Sci. 80, 929-937.

Mould, F.L. \& Ørskov, E.R., 1984. Manipulation of rumen fluid $\mathrm{pH}$ and its influence on cellulolysis in sacco, dry matter degradation and the rumen micro flora of sheep offered either hay or concentrate. Anim. Feed Sci. Technol. 10, 1-14.

Mould, F.L., Ørskov, E.R. \& Mann, S.O., 1983. Associative effects of mixed feeds. I. Effects of type and level of supplementation and the influence of the rumen fluid $\mathrm{pH}$ on cellulolysis in vivo and dry matter digestion of various roughages. Anim. Feed Sci. Technol. 10, 15-30.

Mulvany, P., 1977. Dairy cow condition scoring (Leaflet no 4468). Nat. Inst. for Research in Dairying, Shinfield, RG2 (AT, UK). 
Nocek, J.E. \& Polan, C.E., 1984. Influence of ration physical form of nitrogen availability on rumen fermentation patterns and plasma of growing bull calves. J. Dairy Sci. 67, 1038-1043.

NRC, 2001. Nutrient Requirements of Dairy Cattle, Seventh Rev. Ed. National Research Council, National Academic Press, Washington, D.C., USA.

Ørskov, E.R. \& Istasse, L., 1983. The correlation between extent of $\mathrm{pH}$ depression and degradability of washed hay in sheep given hay and concentrate. Proc. Nutr. Soc. 42, 32A.

Ørskov, E.R. \& McDonald, I., 1979. The estimation of protein degradability in the rumen from incubation measurements weighted according to rate of passage. J. Agric. Sci., Camb. 92, 499-503.

Pitt, R.E., Van Kessel, J.S., Fox, D.J., Pell, A.N., Barry, M.C. \& Van Soest, P.J., 1996. Predictions of rumen volatile fatty acids and $\mathrm{pH}$ within the net carbohydrate and protein system. J. Anim. Sci. 74, 226-244.

Reis, R.B. \& Combs, D.K., 2000. Effects of increasing levels of grain supplementation on rumen environment and lactation performance of dairy cows grazing grass-legume pasture. J. Dairy Sci. 83, 2888-2898.

SAS, 1996. Statistical Analysis Systems Institute (SAS/STAT), User's Guide. Statistics, Release 6.12. SAS Institute, Cary, N.C., USA.

Satter, L.D. \& Slyter, L.L., 1974. Effect of ammonia concentration on rumen microbial protein production in vitro. Br. J. Nutr. 32, 199-225.

Sayers, H.J., 1999. The effect of sward characteristics and level and type of supplement on grazing behaviour, herbage intake and performance of lactating dairy cows. Grass For. Sci. 62, 13-26.

Stockdale, C.R., Wales, B. \& Dalley, D., 2001. Guidelines on the use of high-energy and fibre supplements. DRDC and GippsDairy. Vol. 42 (8), 1757-1760.

Sutton, D.J., Morant, S.V., Bines, J.A., Napper, D.J. \& Givens, D.I., 1993. Effect of altering the starch: fibre ratio in the concentrates on hay intake and milk production by Friesian cows. J. Agric. Sci., Camb. 120, 379-390.

Tilley, J.M. \& Terry, R.A., 1963. A two-stage technique for the in vitro digestion of forage crops. J. Br. Grassl. Soc. 18, 104-111.

Van Soest, P.J., Robertson, J.B. \& Lewis, B.A., 1991. Symposium: Carbohydrate methodology, metabolism, and nutritional implications in dairy cattle. J. Dairy Sci. 74, 3583-3597.

Van Vuuren, A.M., Van der Koelen, J. \& Vroons-de Bruin, J., 1986. Influence of the level and composition of concentrate supplements on rumen fermentation patterns of grazing dairy cows. Neth. J. Agric. Sci. 34, 457-467. 